\title{
Evaluation of the Coating with $\mathrm{TiO}_{2}$ Nanoparticles as an Option for the Improvement of the Characteristics of NiTi Archwires: Histopathological, Cytotoxic, and Genotoxic Evidence
}

\author{
Javier Morán-Martínez $\mathbb{D}^{1},{ }^{1}$ Roberto Beltrán del Río-Parra, ${ }^{1,2}$ \\ Nadia Denys Betancourt-Martínez, ${ }^{1}$ Rubén García-Garza, ${ }^{3}$ Joel Jiménez-Villarreal, ${ }^{4}$ \\ María Soñadora Niño-Castañeda, ${ }^{1}$ Lydia Enith Nava-Rivera, ${ }^{1}$ José Alfredo Facio Umaña, ${ }^{1,2}$ \\ Pilar Carranza-Rosales $\mathbb{D}^{5},{ }^{5}$ and Rubén Daniel Arellano Pérez-Vertti ${ }^{1}$ \\ ${ }^{1}$ Departamento de Biología Celular y Ultraestructura, Centro de Investigación Bioimédica, Facultad de Medicina, \\ Universidad Autónoma de Coahuila, Torreón, COAH, Mexico \\ ${ }^{2}$ Clínica de Ortodoncia, Facultad de Odontología, Universidad Autónoma de Coahuila, Torreón, COAH, Mexico \\ ${ }^{3}$ Departamento de Histología, Facultad de Medicina, Universidad Autónoma de Coahuila, Torreón, COAH, Mexico \\ ${ }^{4}$ Escuela de Medicina, Universidad Autónoma de Coahuila, Unidad Norte, Piedras Negras, COAH, Mexico \\ ${ }^{5}$ Instituto Mexicano del Seguro Social, Centro de Investigación Biomédica del Noreste, Departamento de Biología Celular y Molecular, \\ Monterrey, NL, Mexico \\ Correspondence should be addressed to Javier Morán-Martínez; javmoran@yahoo.com
}

Received 25 July 2017; Revised 29 December 2017; Accepted 18 March 2018; Published 6 May 2018

Academic Editor: Zafar Iqbal

Copyright (C) 2018 Javier Morán-Martínez et al. This is an open access article distributed under the Creative Commons Attribution License, which permits unrestricted use, distribution, and reproduction in any medium, provided the original work is properly cited.

For the EPD, different voltages and different times were used. Male rats were used in four groups $(n=3)$ with different treatments. The blood sample was obtained for genotoxic analysis and liver and kidney organs were removed for histopathological analysis. The amount of $\mathrm{NPs}_{\mathrm{TiO}_{2}}$ deposited on the samples of the arches increases gradually in the times of 15 and 30 s. At all voltages, however,

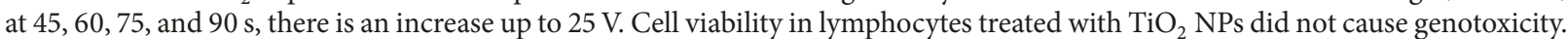
In the histopathological findings of hepatic and renal tissue, nuclear alterations and necrosis were observed. The objective of the study was to improve the physical and biocompatibility characteristics of the NiTi arches for which the EPD is used. The technique for the deposition of $\mathrm{TiO}_{2} \mathrm{NPs}$ was used, where this technique could be used as an economical and versatile way to perform homogeneous depositions even on surfaces with the complexity of the NiTi alloy. As for genotoxicity and cytotoxicity, we continue to have controversial results.

\section{Introduction}

In the recent practice of orthodontics, the use of NickelTitanium (NiTi), Nickel-Titanium-Copper (NiTiCu), or Titanium-Molybdenum (TiMo) alloys predominates due to its elastic characteristics that facilitate the alignment and leveling of the arches, improving the elasticity and flexibility [1]. The use of NiTi arches is widely accepted by the orthodontic community and offers biomechanical benefits difficult to match by some other materials on the market; however, a negative aspect of these arches is the roughness which has the ability to retain a greater amount of dental plaque because it favors its adhesion [2]; principally constituted by aerobic bacteria such as Streptococcus sanguinis and Streptococcus mutans, this plaque propitiates the corrosion of metals and alloys through the formation of organic acids during the 
glycolysis of sugars, reducing the $\mathrm{pH}$ [3]. Currently, the search for improvement of existing materials in the field of orthodontics has been a subject of study; for example, the organically modified antibacterial silicates (ORMOSIL) such as quaternary ammonium methacryloxy silicate (QAMS) is added to the orthodontic acrylic resins in order to improve antimicrobial activity and toughness [4], resin-based adhesion materials contain Portland-type cement to provide adequate shear bond strength (SBS) and a caries-preventive effect [5], the incorporation of bioactive glass (BAG) into composite resins (BAG-Bonds) showed the capacity for buffering acidic oral conditions through the liberation of calcium in the environment [6], and also the modification of the arches with the application of nanomaterials, for example, nanoparticles (NPs), is an interesting topic due to popularity carried in recent times, and the advantages above the other modification techniques are low cost through the use of simple devices and easy handling. Between the diverse types of nanomaterials used in order to improve the arches' characteristics, the nanoparticles of $\mathrm{TiO}_{2}$ have benn shown to be cost-effective [7] and they possess a unique photocatalytic property that results in enhanced microbicide activity, principally against bacterial strains of the plaque [8-10] besides their apparently low toxicity and excellent biocompatibility $[11,12]$; regardless, there is still controversy about it being harmless $[13,14]$, since $\mathrm{TiO}_{2}$ NPs have been related to the induction of cytotoxicity and genotoxicity due to the production of reactive oxygen species (ROS) in different cell types [15-17]; in addition, in vivo studies have shown apparently nanoscale and microscale toxicological effects associated with the size of the nanoparticles of $\mathrm{TiO}_{2}[18,19]$.

The efficacy of electrochemical methods such as electrophoretic deposition (EPD) is an alternative, versatile, and inexpensive procedure for depositing of these nanomaterials [20] and is a very useful tool for the manufacture of films of nanostructures, where thickness can be controlled varying parameters such as voltage and time, principally with the use of $\mathrm{TiO}_{2}$ NPs which have been already proven in the literature; moreover, compared with other wet, dry, or plasma deposition methods, attachment could be oriented more effectively due its nondestructive depositing method that does not affect the particle [21]. The efficiency of EPD in the production of homogeneous and reliable films depends to a great extent on the surface chemistry of the particles, the behavior of surface-liquid interfaces under an electric field, and the development of the particle-particle network and particle-substrate network [22]; because of this, the good quality of $\mathrm{TiO}_{2}$ NPs deposition on stainless steel bars [23] found in the literature does not necessarily correspond to a good deposition quality on other materials including NiTi arches. In our research, we propose an adequate technique for the correct deposition of $\mathrm{TiO}_{2} \mathrm{NPs}$ on the surface of $\mathrm{NiTi}$ arches, since the current bibliographic data in this type of material is virtually nonexistent and the methodology is poor described; for this reason, the objective of this study was to evaluate the electrophoretic deposition (EPD) of $\mathrm{TiO}_{2} \mathrm{NPs}$ in arches as well as their histopathological, genotoxic, and cytotoxic effects in Long-Evans rats.

\section{Materials and Methods}

2.1. Preparation of the NiTi Archwires. Conventional NiTi archwires $(0.017 \times 0.025$ inches $)\left(\right.$ Ah-Kim-Pech ${ }^{\circledR}$, México) were sandblasted with aluminum oxide (Zogear Blaster, $\mathrm{CHN}$ ) and subsequently etched with $10 \%$ oxalic acid at $80^{\circ} \mathrm{C}$ for $60 \mathrm{~min}$ followed by immersion in an ultrasonic bath in acetone for $3 \mathrm{~min}$ and rinsed with distilled water, according to Paoli et al. [22]. To optimize the adhesion of NPs, later the archwires were cut into pieces of $16 \mathrm{~mm}$.

2.2. Suspension Design. A suspension was made for the nanoparticle dispersion with a mixture of $\mathrm{H}_{2} \mathrm{O}$ and $\mathrm{C}_{2} \mathrm{H}_{5} \mathrm{OH}$ (1:4) with a concentration of $\mathrm{TiO}_{2}$ NPs (CAS: 13463-67-7; purity $\geq 99.5 \%$; molecular weight: 79.87; particle size: $21 \mathrm{~nm}$ ), $1 \%$ mass, and poly(diallyl dimethyl ammonium chloride) (PDADMAC) 2\% mass [24] (all chemicals were obtained from Sigma-Aldrich Co., Ltd., St. Luis, MO, USA). The stability of the suspension was obtained by magnetic stirring (hotplate stirrer LMS-1003 Daihan Labtech Co., Ltd., Korea) during $12 \mathrm{~h}$ before the EPD process. This was carried out with two electrodes in a $500 \mathrm{~mL}$ glass vessel; the NiTi archwires were used as deposition substrates and a stainless steel sheet was used as a counter electrode, separated by a distance of $20 \mathrm{~mm}$; both the working electrode and the counter electrode were connected to direct current power supply (Enduro 300V, Labnet International Inc., Woodbridge, NJ, USA). The NiTi archwire samples were weighed on an analytical balance with a sensitivity in $\mu \mathrm{g}$ (Denver Instruments apx-200) and then divided into 6 groups which used a constant voltage $(V)$ of $5,10,15,20,25$, and $30 \mathrm{~V}$, respectively, at different times (15, $30,45,60,75$, and $90 \mathrm{~s}$ ); this was carried out in triplicate. After the EPD the samples were allowed to dry for $24 \mathrm{~h}$ at room temperature; the samples were observed under a 10x optical microscope (Labomed S1100, Germany) with an AmScope MD700 digital microscope to determine the degree of $\mathrm{TiO}_{2}$ NPs deposition. A new weighing of the samples was performed to measure the amount $(\mu \mathrm{g})$ of $\mathrm{TiO}_{2}$ deposited. The amount of $\mathrm{TiO}_{2}$ NPs deposited per area in the NiTi arcs was calculated $\left(\mu \mathrm{g} / \mathrm{mm}^{2}\right)$; the samples were left in a sterile container with $2 \mathrm{~mL}$ of PBS solution for 30 days to administer them later to the experimental group (G3).

\subsection{Determination of the Genotoxicity of $\mathrm{TiO}_{2} \mathrm{NPs}$}

2.3.1. Animals. Our work was developed under the Official Mexican Standard for use and handling of animals in experimentation (SAGARPA in Mexico, NOM-062-ZOO, 1999). The study was approved by the Bioethics Committee and by the Internal Committee for the Care and Use of Laboratory Animals (CICUAL) of the Faculty of Medicine of the Autonomous University of Coahuila (number CONBIOETICA07CEI00320131015). All procedures with experimental animals were supervised by a veterinarian certified by the Secretary of Agriculture, Cattle Raising, Rural Development, Fishing and Food (SAGARPA, key code: MR-0716-33-001-1).

Twelve adult male Long-Evans rats ranging in age from 10 to 12 weeks, with an average weight between 240 and 280 grams, were provided by the Bioterium of the Faculty 
of Medicine of the Autonomous University of Coahuila. All animals were maintained under controlled conditions of temperature at $25-26^{\circ} \mathrm{C}$ in a $12: 12 \mathrm{~h}$ light/dark cycle housed in individual cages with water and food ad libitum.

2.3.2. Experimental Groups and Treatments. The rats were divided into 4 groups; $(n=3)$ the control group (CG) were given $1 \mathrm{~mL}$ of xylocaine ${ }^{\circledR}: 2 \%$ injectable solution of lidocaine without epinephrine intraperitoneally for 3 days, 1 dose daily; the sacrifice was $24 \mathrm{~h}$ after last dose. Group 1 (G1) is given $5 \mathrm{mg} / \mathrm{kg}$ body weight of $\mathrm{TiO}_{2}$ dissolved in $1 \mathrm{~mL}$ xylocaine: $2 \%$ injectable solution of lidocaine without epinephrine intraperitoneally for 3 days, 1 dose daily. The sacrifice was at $48 \mathrm{~h}$ after last dose. Group 2 (G2) is given $5 \mathrm{mg} / \mathrm{kg}$ body weight of $\mathrm{TiO}_{2}$ dissolved in $1 \mathrm{~mL}$ xylocaine: $2 \%$ injectable solution of lidocaine without epinephrine intraperitoneally for 3 days, 1 dose daily. The sacrifice was at $72 \mathrm{~h}$ after last dose. Group 3 (G3) received a solution composed of PBS ( $2 \mathrm{~mL}$ ) NPs of $\mathrm{TiO}_{2}$ plus the arcs NiTi $(25 \mathrm{~V} 90 \mathrm{~s}$ ). This solution remained at rest for 30 days prior to its administration in the rats; this solution was administered by nasogastric tube for 3 days, and the sacrifice was $72 \mathrm{~h}$ after last dose. After the exposure time, the rats were sacrificed by the veterinarian in charge through cervical dislocation; blood samples were extracted by cardiac puncture; the organs (liver and kidney) were removed and fixed in 10\% neutral formalin for subsequent histopathological analysis.

2.3.3. Comet Assay in Lymphocytes. DNA fragmentation analysis of individual cells for peripheral blood lymphocytes was performed based on the methodology of Singh et al. [25] with some minor modifications. This allows the differentiation and analysis of cells with fragmented DNA to determine the percentage of fragmentation using specialized software. From each treatment, $10 \mu \mathrm{L}$ of peripheral blood suspended in $0.5 \%$ low melting point agarose was used on slides pretreated with $0.5 \%$ normal melting point agarose and then covered with coverslips and the agarose was allowed to solidify at $4^{\circ} \mathrm{C}$ per $5 \mathrm{~min}$; the slides were placed in a Köplin with lysis solution (2.5 M NaCl, 0.1 M EDTA, 10\% DMSO, and $1 \%$ Triton X-100). At the end of the lysis, the samples were taken to horizontal electrophoresis chamber and incubated in electrophoresis buffer ( $\mathrm{NaOH} 0.3 \mathrm{M}, 200 \mathrm{mM}$ EDTA) at $\mathrm{pH}=13.0$ to $20 \mathrm{~min}$ at $4^{\circ} \mathrm{C}$ for the unwinding of DNA in a dark room. The electrophoresis was completed with the following specifications: $25 \mathrm{~V}(1 \mathrm{~V} / \mathrm{cm}), 300 \mathrm{~mA}$ for $20 \mathrm{~min}$. After switching off the electrophoresis power source, the electrophoresis chamber slides were carefully removed and rinsed with a neutralization buffer $(0.4 \mathrm{~mol} / \mathrm{L}$ Tris- $\mathrm{HCl}, \mathrm{pH}$ 7.5) for $5 \mathrm{~min}$. The excess of neutralization buffer was drained off and placed in ethanol and then allowed to dry; once dried, the slides were stored for later reading.

2.3.4. DNA Fragmentation Analysis. The DNA was stained in phosphate-buffered saline (PBS) with fluorescent solution of GelGreen $^{\text {TM }}$ (Nucleic Acid Gel Stains, Biotium ${ }^{\circledR}$, Fremont, CA, USA). Comets lymphocytes were evaluated under fluorescence microscope, 40x and 100x (Labomed LX 400,
Germany). The images were taken with a fluorescence, 16megapixel digital camera (AmScope, Digital Camera Microscope \# MD700) and were converted into Bitmaps format ( ${ }^{*}$.bmp) and analyzed in TriTek's CometScore Freeware v1.5 software. Image J software V.1.8.0 was first used to remove background noise from the DNA images obtained. Automatic image processing software was used for analysis of the comet assay. The software was able to calculate the amount of DNA at specified location based on pixel intensity of images. DNA in the tail was computed as follows:

$$
\mathrm{DNA}=\frac{\text { total comet tail intensity }}{\text { total comet intensity }} \times 100 \text {. }
$$

2.4. Histopathological Analysis. At the end of the experimental period, the rats were sacrificed by cervical dislocation; blood samples were collected by cardiac puncture and dissection of the abdominal organs was performed and fixed in $10 \%$ neutral formalin for subsequent histological analysis. Representative samples of hepatic and renal tissue previously fixed to be included in paraffin blocks were taken by conventional histological technique, which were cut in a microtome (Leitz 1512, Austria) at a thickness of $5 \mu \mathrm{m}$ and mounted on slides stained with hematoxylin and eosin ( $\mathrm{H} \& \mathrm{E})$. The stained sections were examined under light microscopy to make the respective observations and to evaluate the morphological changes comparing them with the control tissues.

2.5. Statistical Analysis. We performed Kruskal-Wallis test as a nonparametric test and Dunn test as a post hoc test and unidirectional ANOVA as a parametric test using Tukey as a post hoc test. Measures of central tendency and standard deviation were done. Statistical analysis was performed using the Minitab 17 software for Windows.

\section{Results}

3.1. Deposition of Arches with $\mathrm{TiO}_{2}$. The EPD gives us the possibility of generating different rate of amount of $\mathrm{TiO}_{2}$ NPs deposited per area of NiTi arch (Figure 2) by the modulation of applied voltage and the time of deposition. In our experiment, the amount of $\mathrm{TiO}_{2}$ NPs deposited on the samples of the arches increases gradually at the times of 15 and $30 \mathrm{~s}$ at all voltages (Figures 1(a) and 1(b)); however, at 45, 60,75 , and $90 \mathrm{~s}$, there is an increase up to $25 \mathrm{~V}$ (Figures 1 (c), $1(\mathrm{~d}), 1(\mathrm{e})$, and $1(\mathrm{f}))$. It was observed that the samples with higher deposition of $\mathrm{TiO}_{2}$ NPs were $25 \mathrm{~V} 90 \mathrm{~s}$ and $30 \mathrm{~V} 90 \mathrm{~s}$ (Figures 4(f) and 4(g)). However, in these samples, a large number of fractures were observed in the continuity of the coating; the best ratio between quantity and quality of the coatings obtained by the deposition of $\mathrm{TiO}_{2} \mathrm{NPs}$ in the treated samples, finding the most homogeneous and fracture free coating, was in the sample of 10 V75 s (Figure 4(c)). In the results, a constant increase in the amount of deposited $\mathrm{TiO}_{2}$ from $15 \mathrm{~V}$ to $25 \mathrm{~V}$ in all the treated arches could be observed; a variable behavior was found in voltages under $15 \mathrm{~V}$ and greater than $25 \mathrm{~V}$. The correlation of the DEF of the $\mathrm{TiO}_{2}$ NPs at times of 15 and $30 \mathrm{~s}, 45$ and $60 \mathrm{~s}, 75$ and $90 \mathrm{~s}$ was highly significant as observed in the correlation 


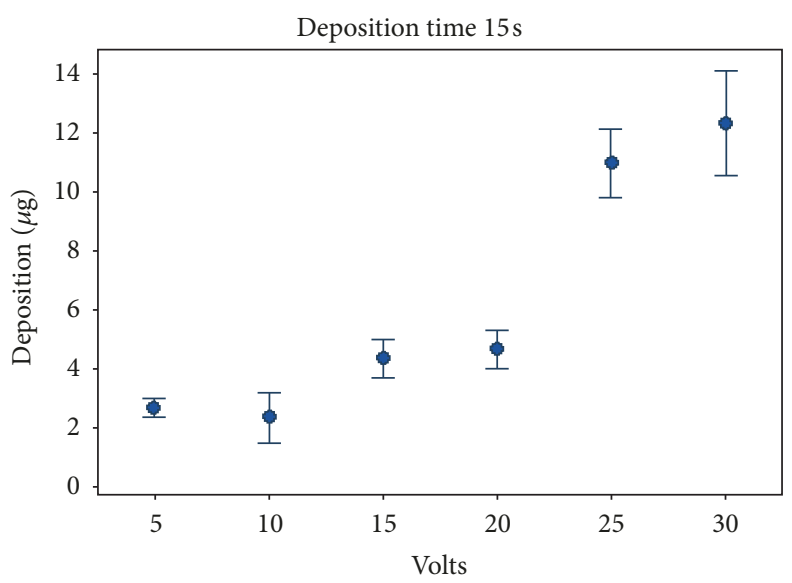

(a)

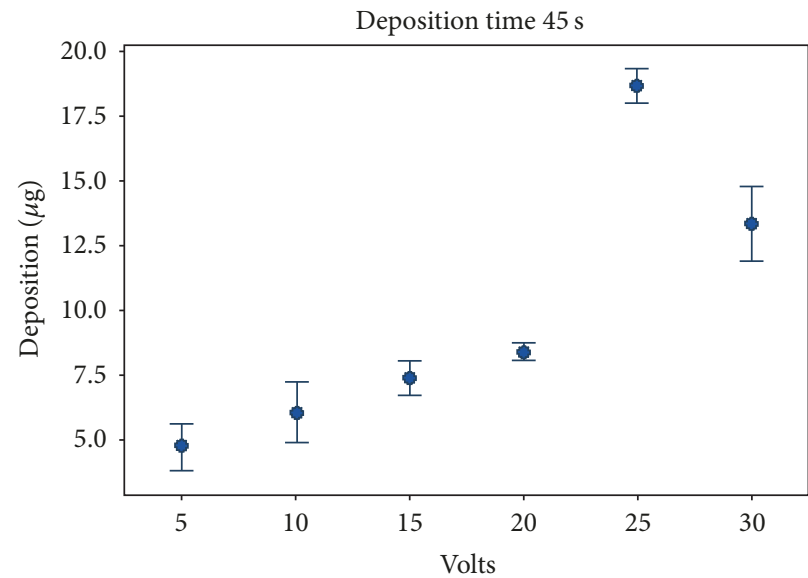

(c)

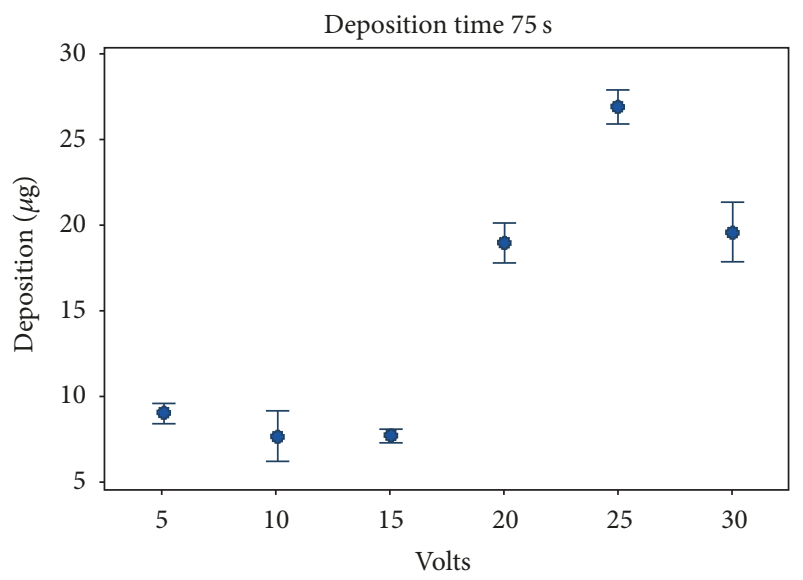

(e)

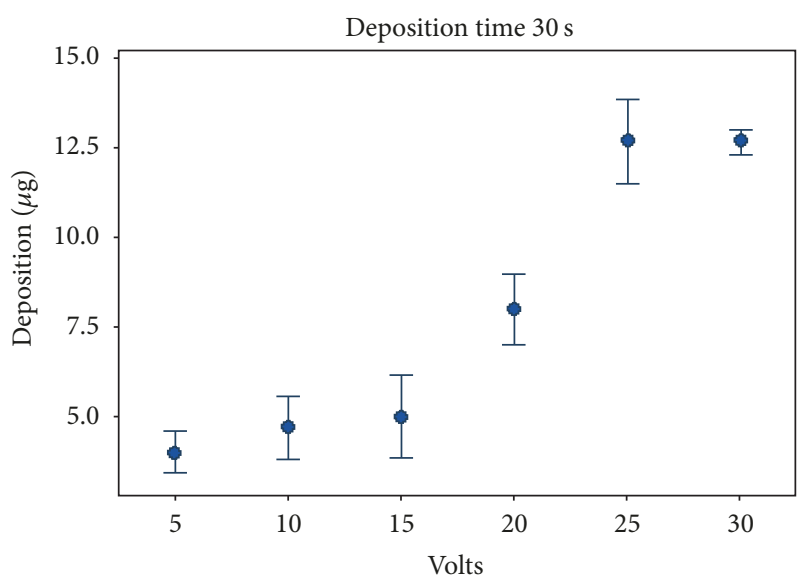

(b)

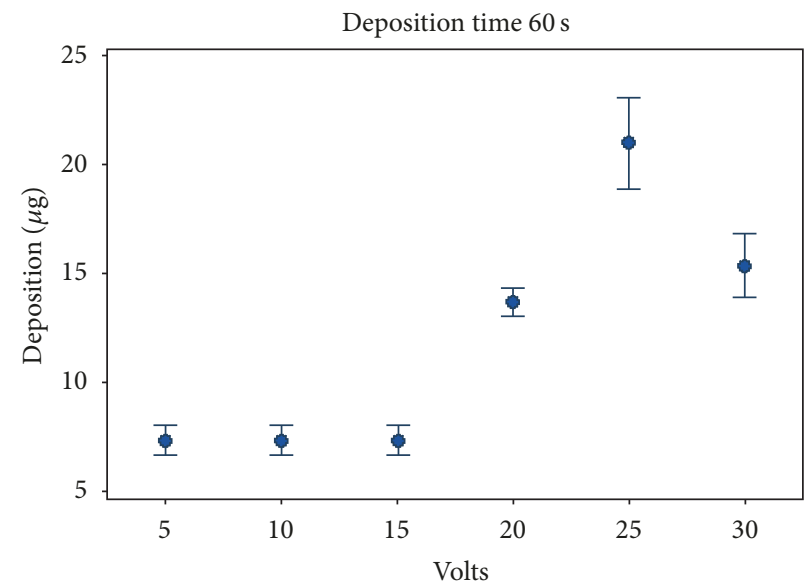

(d)

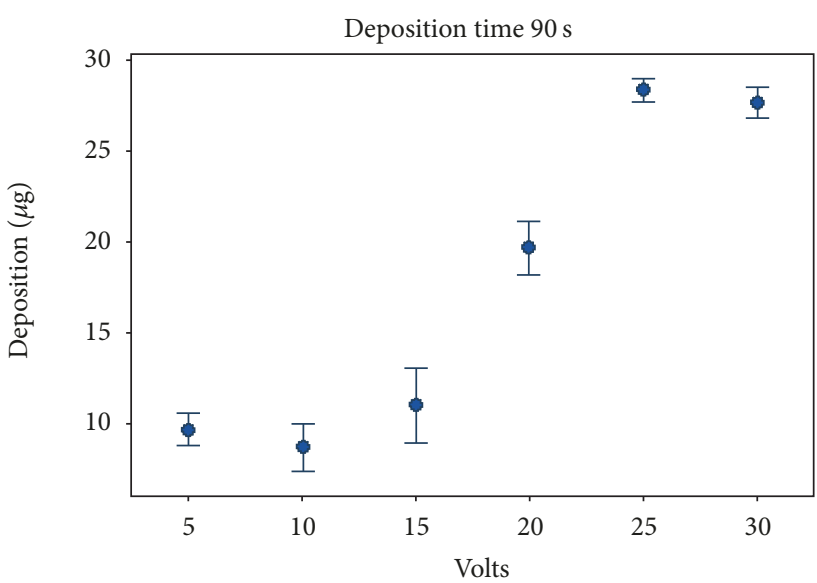

(f)

Figure 1: Deposition of $\mathrm{TiO}_{2}$ NPs ( $\mu$ g) voltage (V)/time (s). (a) 15, (b) 30, (c) 45, (d) 60, (e) 75, and (f) 90 seconds versus 10, 15, 20, 25, and $30 \mathrm{~V}$ for each deposition. Results are shown in mean and standard error.

graphs (Figures 3(a)-3(c)). This indicates and corroborates what was mentioned above, where, according to the voltage intensity and elapsed time of the DEF, we observed this trend of dependent association because of the voltage with the time of application of voltage to which the arch was submitted.
In the microphotographs, we can see the different groups of arcs with their voltages and their effects (Figure 4). In the group of 5 volts (Figure 4(a)), it was observed that the deposition is minimal; increasing the voltage shows a larger deposition, considering the uniformity of the EPD at $10 \mathrm{~V} 75 \mathrm{~s}$ 


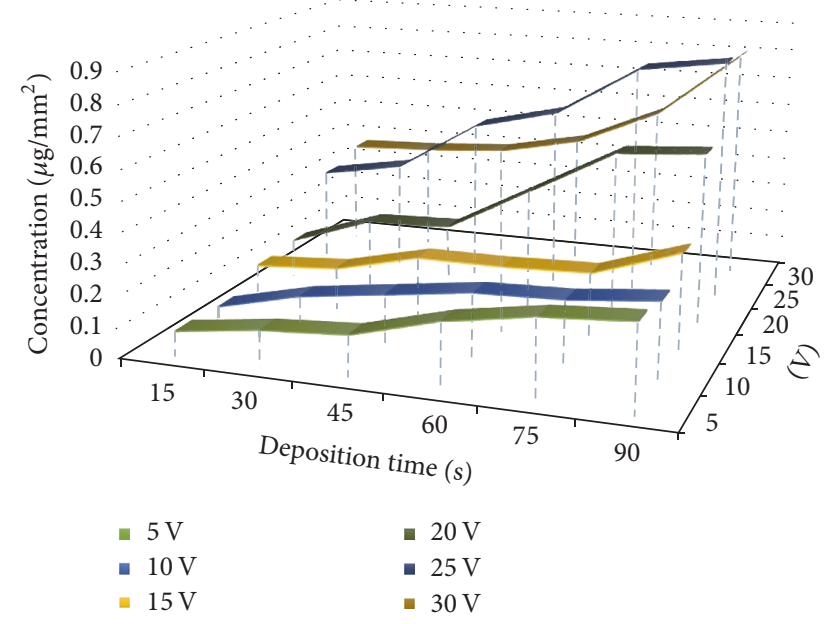

Figure 2: Amount of deposition of $\mathrm{TiO}_{2} \mathrm{NPs}(\mu \mathrm{g})$ per area of NiTi $\operatorname{arch}\left(\mu \mathrm{g} / \mathrm{mm}^{2}\right)$ (voltage $(\mathrm{V}) /$ time $\left.(\mathrm{s})\right) .15,30,45,60,75$, and $90 \mathrm{~s}$ versus $5,10,15,20,25$, and $30 \mathrm{~V}$ for each deposition.

(Figure 4(c)), the greater amount of deposition is obtained at $25 \mathrm{~V}$ to $90 \mathrm{~s}$ (Figure 4(f)). The general behavior is that from $15 \mathrm{~V}$ there is a sustained increase of NPs deposited up to $30 \mathrm{~V}$ where there is a decrease because it exceeds the value of the critical cracking thickness (EAC).

\subsection{Analysis of DNA Fragmentation by Exposure to $\mathrm{NPs}$ of $\mathrm{TiO}_{2}$}

3.2.1. DNA Fragmentation in Lymphocytes. When the alkaline comet test was performed, a stability was observed in the DNA chain, since there was no significant migration on this (Figure 5); treatment with $\mathrm{TiO}_{2} \mathrm{NPs}$ did not cause cytotoxicity at the concentration of $5 \mathrm{mg} / \mathrm{kg}$ for 3 days, 1 daily dose, with the sacrifice being conducted after the last dose at $48 \mathrm{~h}$ (G1). There was also no cytotoxicity at the concentration of $5 \mathrm{mg} / \mathrm{kg}$ for 3 days, 1 daily dose, with the sacrifice being conducted after the last dose at $72 \mathrm{~h}$ (G2) or in the PBS solution $(2 \mathrm{~mL})$ in which previously treated arches were submerged ( $25 \mathrm{~V} 90 \mathrm{~s}$ ) and left to rest for 30 days and administered by nasogastric tube for 3 days and with a sacrifice conducted after the last dose of $72 \mathrm{~h}$ (G3), suggesting that there were no DNA breaks (see Figure 5(c)). Another parameter delivered by the comet test is the percentage of DNA contained in the comet tail. This parameter is the subtraction of $100 \%$ of DNA minus the percentage of DNA contained in the head of the comet. This parameter is the percentage of fragmentation that the evaluated cell has; the group with greater fragmentation was group 1 (G1) which had an average of $6.06 \pm 1.49$ percent.

3.3. Histopathological Findings. Figure 6 shows the microphotographs with the observations found in liver tissue samples. In the analysis of the samples corresponding to the control group, which was administered only with $2 \%$ lidocaine for 3 days, no pathological data were found
(Figure 6(a)). In those corresponding to group 1, which received $5 \mathrm{mg} / \mathrm{kg} \mathrm{TiO}$ for 3 days, being sacrificed $48 \mathrm{~h}$ after the last dose, the presence of vacuoles included within the hepatocyte cytoplasm was observed (Figure 6(b)). In the case of group 2 samples, they received $5 \mathrm{mg} / \mathrm{kg}$ of $\mathrm{TiO}_{2}$ for three days and were sacrificed $72 \mathrm{~h}$ after the last dose; it is observed that the hepatocytes present a foamy cytoplasm and nucleus with granular chromatin (Figure 6(c)). Group 3, which was given PBS solution for 3 days in which the $\mathrm{TiO}_{2}$ treated arches rested and were sacrificed $72 \mathrm{~h}$ after the last dose, extensive areas of cell necrosis were observed with destruction of hepatocytes (Figure 6(d)). Figure 7 shows the representative microphotographs, corresponding to the findings in renal tissue samples. In the analysis of the samples from the control group, no pathological data were found. In the samples corresponding to groups 1,2 , and 3 , a slight glomerular retraction and moderate vascular congestion were observed.

\section{Discussion}

4.1. Electrophoretic Deposition. In the course of achieving the final suspension design, 3 mixtures were used, a mixture of $\mathrm{H}_{2} \mathrm{O}$ and $\mathrm{NaCl}$ without charging agent (data not shown), a mixture of $\mathrm{H}_{2} \mathrm{O}$ and $\mathrm{C}_{2} \mathrm{H}_{5} \mathrm{OH}(1: 4)$ and the polyethylenimine (PEI) charging agent (data not shown), and a mixture of $\mathrm{H}_{2} \mathrm{O}$ and $\mathrm{C}_{2} \mathrm{H}_{5} \mathrm{OH}(1: 4)$ and the poly(diallyl dimethyl ammonium chloride) (PDADMAC) charging agent, which proved to be the best combination to enhance the adhesion effect of $\mathrm{TiO}_{2} \mathrm{NPs}$ layers. It was observed that the mixture of $\mathrm{H}_{2} \mathrm{O}$ and $\mathrm{NaCl}$ because of being a water-based solution produces electrolysis even at low voltages and this causes bubbles to be trapped causing "gaps" in the deposition of the $\mathrm{TiO}_{2}$ NPs, coinciding with what was commented on in [26-28]. Therefore, it was decided to use an ethanolbased suspension instead of water in order to avoid harmful hydrogen penetration at the working electrode and a charging agent was added to provide an additional surface charge for the stabilization of suspended particles and electrophoretic mobility during the deposition process $[29,30]$. To the mixtures based on $\mathrm{H}_{2} \mathrm{O}$ and $\mathrm{C}_{2} \mathrm{H}_{5} \mathrm{OH}(1: 4)$ a charging agent of PEI and PDADMAC were added, respectively, having the best adhesion results with the PDADMAC charging agent, coinciding with the results of Lau and Sorrell [29]. In the researches conducted by González-Luna et al. and Wu et al. $[12,31]$, they suggest a deposition in the range of $20-50 \mathrm{~V}$, and Boccaccini et al. [32] suggest ranges from 10 to $50 \mathrm{~V}$; in our study the voltage range was handled between 5 and $30 \mathrm{~V}$ with the largest amount of deposition in the $25 \mathrm{~V}$ regardless of time, unlike Paoli et al. [22] who suggest $20 \mathrm{~V}$ as the most optimal voltage and Hasegawa et al. [33] who suggest $40 \mathrm{~V}$. This study confirms what other authors observed when the amount of deposited layers was modulated with the deposition time and the voltage, although not necessarily more time and voltage mean a better deposition. In our study, with the combination of the voltage/time deposition, the most homogeneous layers obtained without fractures were with the samples of $10 \mathrm{~V} / 75 \mathrm{~s}$. Samples under this voltage show very little deposition and those superior to it show 


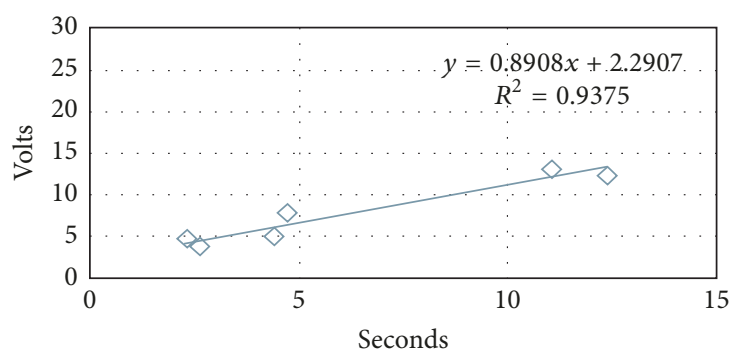

(a)

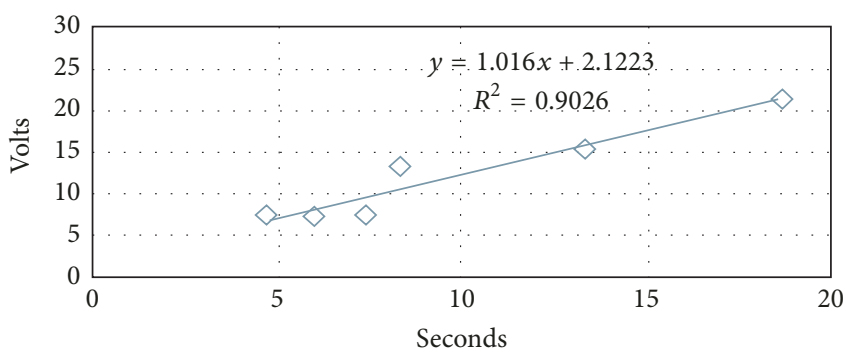

(b)

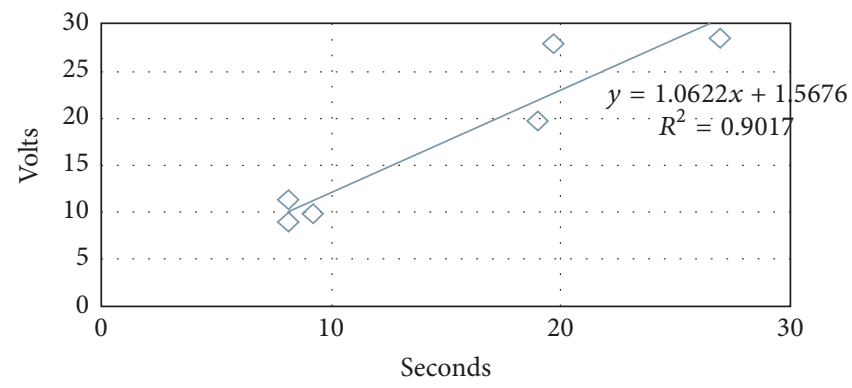

(c)

Figure 3: Time/voltage correlation. A voltage-dependent association tendency was observed with the time of voltage application. Notes: (a) deposition, 15 and $30 \mathrm{~s}$, (b) deposition, 45 and $60 \mathrm{~s}$, and (c) deposition, 75 and $90 \mathrm{~s}$.

greater deposition but with fractures, which increases the time of deposition/voltage. After having a constant increase, the samples treated at $30 \mathrm{~V}$ have a decrease in the deposited $\mathrm{TiO}_{2}$ NPs, as can be seen in the deposition's interval graphs; the possible explanation for this is that it exceeds the value of the critical cracking thickness (CCT) as explained by Sadeghi et al. [30]. When the layer becomes thicker during the deposition process, there is an increase in the resistance because the previously deposited layer is nonconductive, weakening the electric force field and causing weak connections between the particles along the final layer. Therefore, the accumulated NPs on that layer tend to have fractures that cause the detachment of the NPs due to the accumulated excess. It was decided not to perform any sintering technique after EPD because it has been proven that the exposure of the NiTi archwires at temperatures above $500^{\circ} \mathrm{C}$ alters their mechanical properties [34-36].

4.2. Comet Assay. Although administration of $\mathrm{TiO}_{2} \mathrm{NPs}$ to the experiment animals was intraperitoneally (G1 and G2) and through nasogastric probe (G3), there was no significant induction of DNA breaks in peripheral blood lymphocytes in the results delivered by the comet assay; our negative results were similar to those found in keratinocytes, irradiated with $\mathrm{TiO}_{2}$ at 20, 40, and $60 \mathrm{~min}$, where there was no evidence of type IV comet damage and the number of comets II and III was approximately $30 \%$ [37] also in human diploid fibroblasts and human bronchial epithelial cells that were exposed at concentrations up to $50 \mu \mathrm{g} / \mathrm{cm}^{2}$ where the tail moment does not exceed [15]. But, as mentioned above, there are studies where positive results were found in the comet assays, for example, in lymphocytes, which were treated with $\mathrm{TiO}_{2}$ at concentrations up to $59.7 \mu \mathrm{g} / \mathrm{mL}$ having a mean of olive moment of $7.30 \pm 0.81$ [38], human bronchial cell cultures that were treated with $1.77 \mathrm{~g} / \mathrm{cm}^{2} \mathrm{TiO}_{2}$ NPs causing olive moments up to 90 [17], Rtg cells exposed for $4 \mathrm{~h}$ to $\mathrm{TiO}_{2} \mathrm{NPs}(50 \mu \mathrm{g} / \mathrm{mL})$ in MEM cultures PBS, and $\mathrm{H}_{2} \mathrm{O}$ solution where there was a percentage of DNA in tail of 32,45 , and 32 , respectively [39]. These inconsistent results may be due to the different sizes and structures of the $\mathrm{TiO}_{2}$ NPs used in the studies as suggested [40], making it difficult to compare the results between the studies.

4.3. Pathophysiological Findings. The results of the present study show the existence of cytotoxic potential of $\mathrm{TiO}_{2} \mathrm{NPs}$ after acute exposure by intraperitoneal injection (G2 and G3) at a high dose as presented in our methodology and coinciding with Singh et al. [25] with progressive damage even after cessation of exposure, supporting the distribution and accumulation data in liver and kidney [41]. In the case of G3, the liver damage was a lot greater, represented by the extensive areas of cellular necrosis. There was not enough time to find fibrous septa (cirrhosis) in the liver parenchyma as in the findings reported by Umbreit et al. [42] where central fibrous septa were found after 7 days of exposure. In the case of renal damage analysis, the findings were more discrete and there was no significant difference in the cases exposed to a controlled concentration compared to those that received the PBS solution in which the deposited archwires rested. In this case, contrary to the findings of Chen et al. [43], what was observed in our study was a glomerular contraction and not a glomerular inflammation. Our observations seem to indicate that, after deposition of $\mathrm{TiO}_{2} \mathrm{NP}, \mathrm{NiTi}$ arcs that exceed the CCT, for example, samples of $25 \mathrm{~V} / 90 \mathrm{~s}$, are susceptible to degradation of the coating in an aqueous medium (PBS solution), when ingests are absorbed and $\mathrm{TiO}_{2}$ 


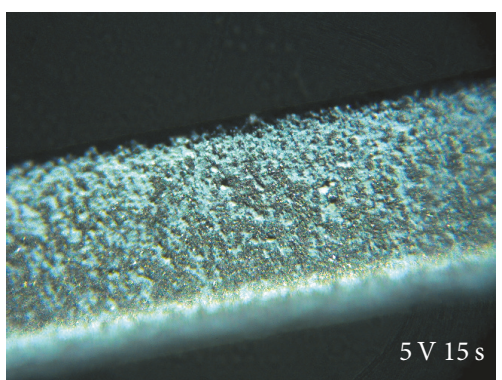

(a)

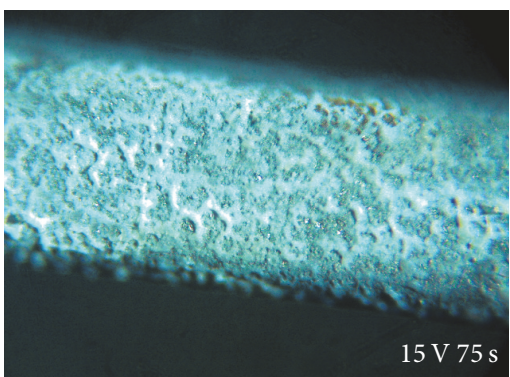

(d)

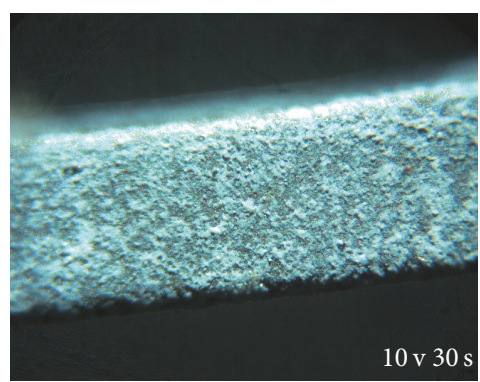

(b)

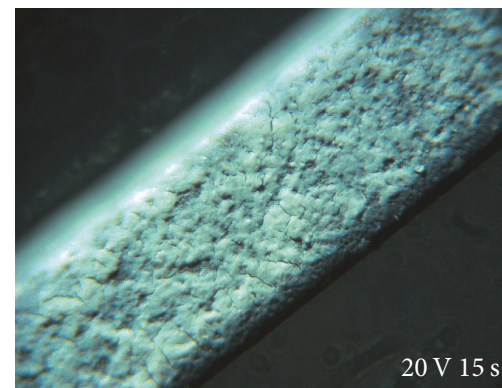

(e)

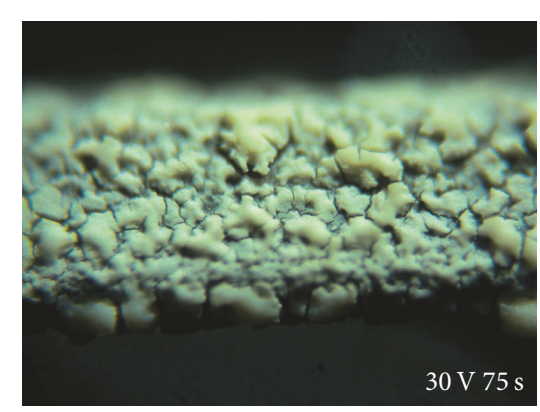

(g)

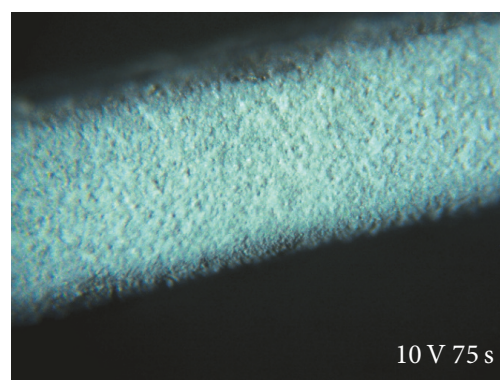

(c)

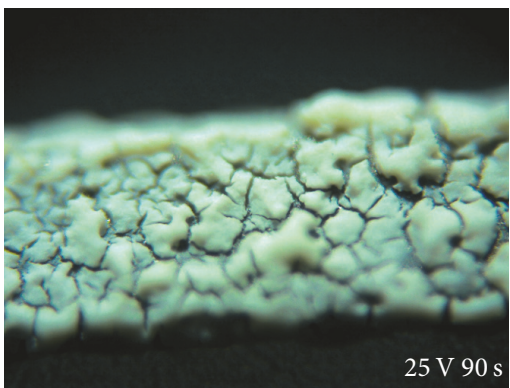

(f)

Figure 4: Deposited arches. It is observed that, at higher voltage/deposition time, there are more deposited $\mathrm{TiO}_{2} \mathrm{NPs}_{\mathrm{s}}$ but there is also an increase in surface fractures ((f) and (g)) (10x).

NPs enter the bloodstream producing a toxic effect on the organs, with the first step being the liver parenchyma, which results in extensive lesions such as those found in our study. Other studies describe the ability of $\mathrm{TiO}_{2} \mathrm{NPs}$ to produce an inflammatory response and induce the production of ROS (reactive oxygen species) inducing apoptosis, as observed in our results [44], in addition to mentioning the relationship between the size of the NPs and their toxicity, suggesting that the smaller the size, the greater the metabolic activity and toxicity. Regarding the intracellular mechanisms of damage [45], when describing the importance of the internalization of NPs of $\mathrm{TiO}_{2}$, when they accumulate in lysosomes, this leads to their rupture and releases their content, such as cathepsin $B$ with the subsequent activation of caspases to apoptosis.

\section{Conclusion}

The aim in this study was to improve the physical and biocompatibility characteristics of the NiTi arches; therefore the EPD technique was conducted to deposit $\mathrm{TiO}_{2} \mathrm{NPs}$, thus proving the success of the method as a low-cost and versatile way of performing homogenous depositions even on complex surfaces such as NiTi alloys; the quality of the deposition was controlled with an adequate voltage, a precise time, and an ideal charging agent. With regard to genotoxicity and cytotoxicity, controversial results were still found, in agreement with other authors of the related literature; for example, our results in the comet assays suggest that there is no genotoxicity in any of the experimental groups under the conditions conducted. Nevertheless, in the cytotoxic findings, cytotoxic potential in the $\mathrm{TiO}_{2}$ NPs was found, representing progressive damage even after the cessation of exposition and in some cases it was the G3 cellular necrosis. At the end, the use of $\mathrm{NiTi}$ arches coated with $\mathrm{TiO}_{2}$ is not recommended to be placed in the mouth until more experimental research is done about friction resistance and degradation in the oral environment, as well as testing of $\mathrm{TiO}_{2} \mathrm{NPs}$ with long term exposition in vivo. 


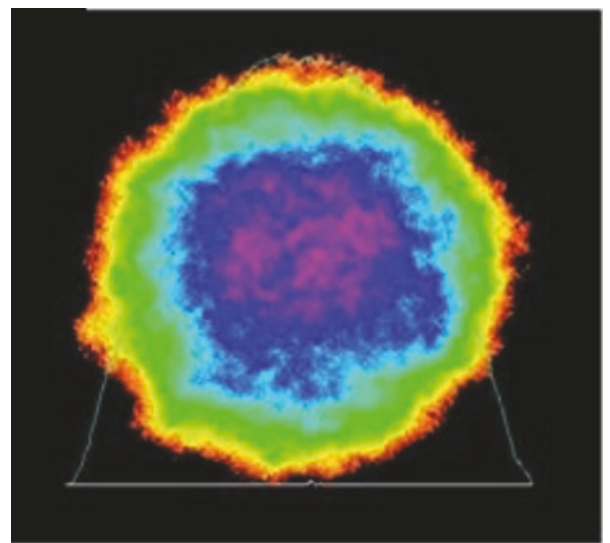

(a)

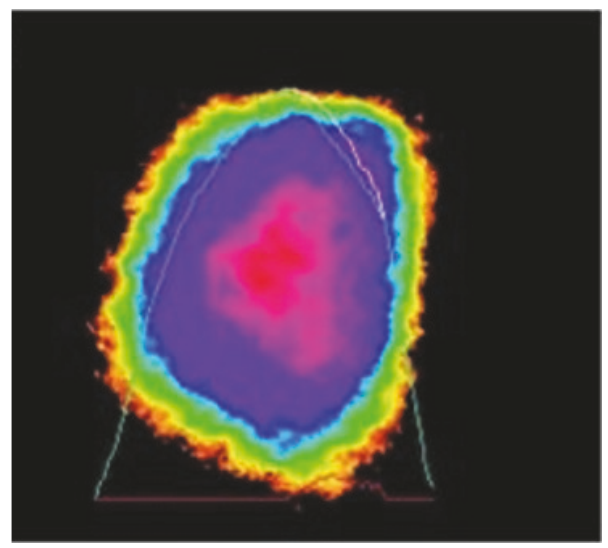

(c)

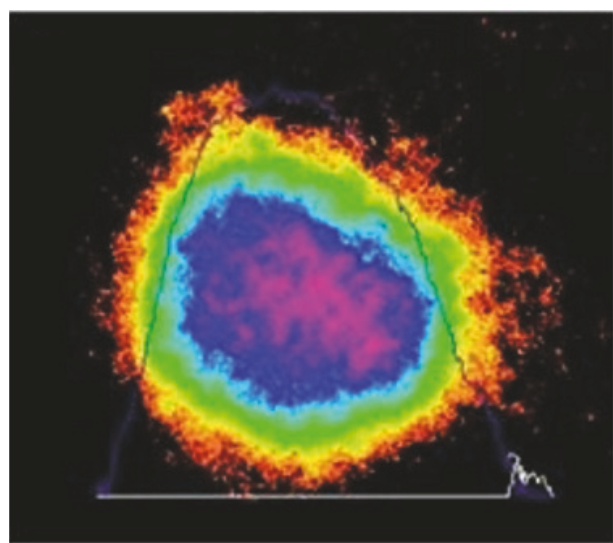

(b)

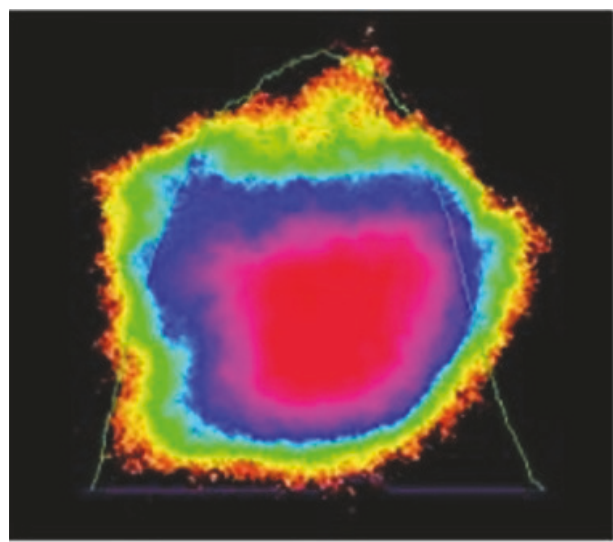

(d)

Figure 5: Analysis of the cells with the CometScore ${ }^{T M}$ program for DNA measurement at the comet head, where GC, G1, G2, and G3 ((a), (b), (c), and (d)) showed no significant migration $(P>0.05)$.

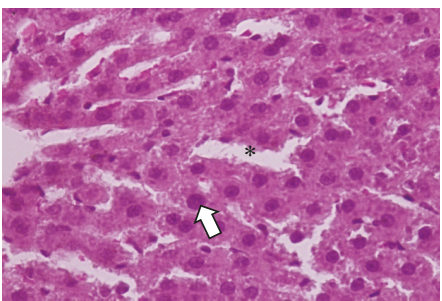

(a)

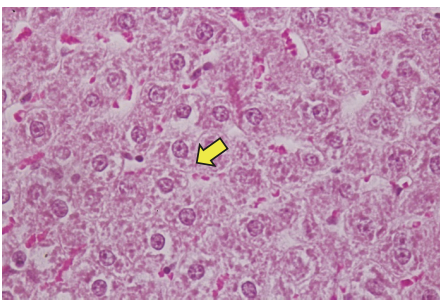

(c)

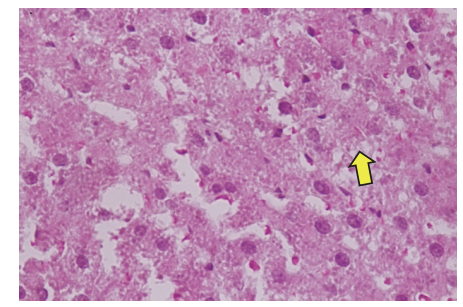

(b)

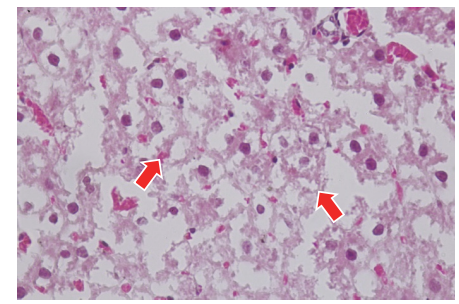

(d)

Figure 6: Microphotograph of liver dyed with H\&E at 40x. (a) Control group, showing sinusoids (*) and hepatocyte cords (white arrow) with nucleus and cytoplasm of typical morphological characteristics. (b) In rats of group 1, few vacuoles in the hepatocytes cytoplasm are observed (yellow arrow). (c) In group 2, abundant intracytoplasmic vacuoles are observed (yellow arrow). (d) In group 3, tissue necrosis areas with hepatocytes destruction are observed (red arrow). 


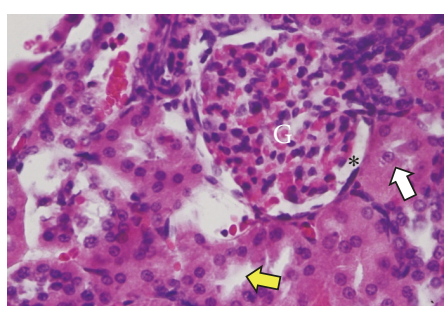

(a)

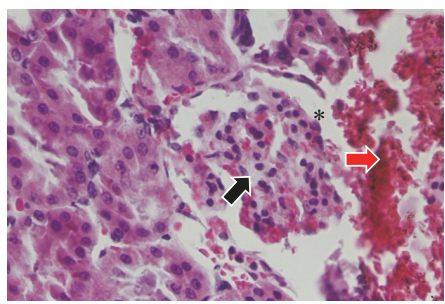

(c)

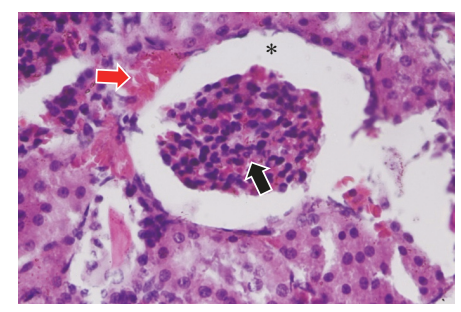

(b)

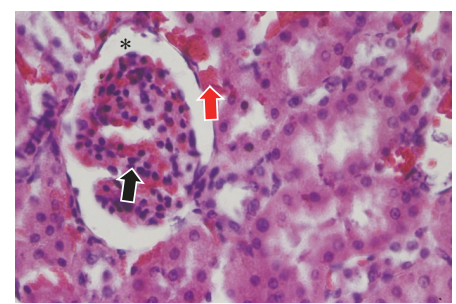

(d)

Figure 7: Microphotomicrograph of kidney dyed with H\&E at 40x. (a) Control group with normal histopathological characteristics, glomerulus $(\mathrm{G})$, urinary space $(*)$, proximal convoluted tubule (white arrow), and distal tubules (yellow arrow) are observed. In 1,2 , and 3 experimental groups (microphotographs b, c, and d, resp.) glomerular retraction (black arrows), an increase of urinary space (*), and mild vascular congestion (red arrow) are observed.

\section{Conflicts of Interest}

The authors declare that they have no conflicts of interest.

\section{Acknowledgments}

Roberto Beltrán del Río-Parra and José Alfredo Facio Umaña were supported by CONACyT scholarships (\#285474 and \#285473, resp.). The authors wish to acknowledge Programa Integral de Fortalecimiento Institucional (PIFI, Secretaría de Educación Pública, México) for partial support for Roberto Beltrán del Río-Parra and José Alfredo Facio Umaña for the stay at the Laboratory of the Dental Materials Department of the Faculty of Dentistry of Niigata University (Niigata, Japan). They acknowledge Coordinación General de Estudios de Posgrado e Investigación of Universidad Autónoma de Coahuila and Consejo Estatal de Ciencia y Tecnología del Estado de Coahuila (Grant no. COAH-2016-C11-A02) for partial support of the study.

\section{References}

[1] W. A. Brantley, "Orthodontic materials," Scientific and Clinical Aspects, pp. 78-100, 2000.

[2] C. Ábalos, "Adhesión bacteriana a biomateriales," Avances en Odontoestomatología, vol. 21, no. 1, pp. 347-353, 2005.

[3] T. P. Chaturvedi, Corrosion behaviour of orthodontic alloys-a review [PhD Thesis], Banaras Hindu University Varanasi, 2008.

[4] S.-Q. Gong, J. Epasinghe, F. A. Rueggeberg et al., "An ORMOSIL-containing orthodontic acrylic resin with concomitant improvements in antimicrobial and fracture toughness properties," PLoS ONE, vol. 7, no. 8, Article ID e42355, 2012.
[5] M. Iijima, M. Hashimoto, S. Nakagaki et al., "Bracket bond strength and cariostatic potential of an experimental resin adhesive system containing Portland cement," The Angle Orthodontist, vol. 82, no. 5, pp. 900-906, 2012.

[6] M. L. Brown, H. B. Davis, E. Tufekci, J. J. Crowe, D. A. Covell, and J. C. Mitchell, "Ion release from a novel orthodontic resin bonding agent for the reduction and/or prevention of white spot lesions An in vitro study," The Angle Orthodontist, vol. 81, no. 6, pp. 1014-1020, 2011.

[7] C. Nagelreiter, H. Kotisch, T. Heuser, and C. Valenta, "Size analysis of nanoparticles extracted from W/O emulsions," International Journal of Pharmaceutics, vol. 488, no. 1-2, pp. 2932, 2015.

[8] F. Ahrari, N. Eslami, O. Rajabi, K. Ghazvini, and S. Barati, “The antimicrobial sensitivity of Streptococcus mutans and Streptococcus sangius to colloidal solutions of different nanoparticles applied as mouthwashes," Dental Research Journal, vol. 12, no. 1, pp. 44-49, 2015.

[9] A. Sodagar, M. S. A. Akhoundi, A. Bahador et al., "Effect of TiO2 nanoparticles incorporation on antibacterial properties and shear bond strength of dental composite used in orthodontics," Dental Press Journal of Orthodontics, vol. 22, no. 5, pp. 67-74, 2017.

[10] Y. Xing, X. Li, L. Zhang et al., "Effect of $\mathrm{TiO}_{2}$ nanoparticles on the antibacterial and physical properties of polyethylene-based film," Progress in Organic Coatings, vol. 73, no. 2-3, pp. 219-224, 2012.

[11] Z. Fei Yin, L. Wu, H. Gui Yang, and Y. Hua Su, "Recent progress in biomedical applications of titanium dioxide," Physical Chemistry Chemical Physics, vol. 15, no. 14, pp. 4844-4858, 2013.

[12] P.-I. González-Luna, G.-A. Martinez-Castanon, N.-V. ZavalaAlonso et al., "Bactericide effect of silver nanoparticles as a final irrigation agent in endodontics on enterococcus faecalis: 
an ex vivo study," Journal of Nanomaterials, vol. 2016, Article ID 7597295, 7 pages, 2016.

[13] M. Hamzeh and G. I. Sunahara, "In vitro cytotoxicity and genotoxicity studies of titanium dioxide $\left(\mathrm{TiO}_{2}\right)$ nanoparticles in Chinese hamster lung fibroblast cells," Toxicology in Vitro, vol. 27, no. 2, pp. 864-873, 2013.

[14] H. Shi, R. Magaye, V. Castranova, and J. Zhao, "Titanium dioxide nanoparticles: a review of current toxicological data," Particle and Fibre Toxicology, vol. 10, no. 1, article 15, 2013.

[15] K. Bhattacharya, M. Davoren, J. Boertz, R. P. F. Schins, E. Hoffmann, and E. Dopp, "Titanium dioxide nanoparticles induce oxidative stress and DNA-adduct formation but not DNAbreakage in human lung cells," Particle and Fibre Toxicology, vol. 6, article 17, 2009.

[16] G. C. M. Falck, H. K. Lindberg, S. Suhonen et al., "Genotoxic effects of nanosized and fine TiO2," Human \& Experimental Toxicology, vol. 28, no. 6-7, pp. 339-352, 2009.

[17] J. R. Gurr, A. S. S. Wang, C. H. Chen, and K. Y. Jan, "Ultrafine titanium dioxide particles in the absence of photoactivation can induce oxidative damage to human bronchial epithelial cells," Toxicology, vol. 213, no. 1-2, pp. 66-73, 2005.

[18] G. Oberdörster, J. Ferin, G. Finkelstein, P. Wade, and N. Corson, "Increased pulmonary toxicity of ultrafine particles? II. Lung lavage studies," Journal of Aerosol Science, vol. 21, no. 3, pp. 384$387,1990$.

[19] G. Oberdorster, J. Ferin, R. Gelein, S. C. Soderholm, and J. Finkelstein, "Role of the alveolar macrophage in lung injury: Studies with ultrafine particles," Environmental Health Perspectives, vol. 97, pp. 193-199, 1992.

[20] A. R. Boccaccini, S. Keim, R. Ma, Y. Li, and I. Zhitomirsky, "Electrophoretic deposition of biomaterials," Journal of the Royal Society Interface, vol. 7, no. 5, pp. S581-S613, 2010.

[21] R. Kawakami, K. Ito, Y. Sato, Y. Mori, M. Adachi, and S. Yoshikado, "Preparation and evaluation of $\mathrm{TiO} 2$ nanoparticle thin films using electrophoresis deposition method," IOP Conference Series Materials Science and Engineering, vol. 18, no. 6, p. 62011, 2011.

[22] E. Paoli, G. Cappelletti, and L. Falciola, "Electrochemistry as a tool for nano-TiO2 deposition and for photoremediation pollutant monitoring," Electrochemistry Communications, vol. 12, no. 8, pp. 1013-1016, 2010.

[23] L. E. Vieira, K. C. Kleinjohann, J. B. R. Neto, A. N. Klein, D. Hotza, and R. Moreno, "Dip coating of a carbon steel sheet with Ni reinforced TiO2 nanoparticles," Materials Research, vol. 19, no. 3, pp. 648-653, 2016.

[24] Y. Sun and I. Zhitomirsky, "Electrophoretic deposition of titanium dioxide using organic acids as charging additives," Materials Letters, vol. 73, pp. 190-193, 2012.

[25] N. P. Singh, M. T. McCoy, R. R. Tice, and E. L. Schneider, "A simple technique for quantitation of low levels of DNA damage in individual cells," Experimental Cell Research, vol. 175, no. 1, pp. 184-191, 1988.

[26] L. Besra and M. Liu, "A review on fundamentals and applications of electrophoretic deposition (EPD)," Progress in Materials Science, vol. 52, no. 1, pp. 1-61, 2007.

[27] O. O. Van Der Biest and L. J. Vandeperre, "Electrophoretic deposition of materials," Annual Review of Materials Research, vol. 29, pp. 327-352, 1999.

[28] T. Uchikoshi, K. Ozawa, B. D. Hatton, and Y. Sakka, "Dense, bubble-free ceramic deposits from aqueous suspensions by electrophoretic deposition," Journal of Materials Research, vol. 16, no. 2, pp. 321-324, 2001.
[29] K. T. Lau and C. C. Sorrell, "Effect of charging agents on electrophoretic deposition of coarse titanium particles," Journal of The Australian Ceramic Society, vol. 49, no. 2, pp. 108-115, 2013.

[30] A. A. Sadeghi, T. Ebadzadeh, B. Raissi, S. Ghashghaie, and S. M. A. Fateminia, "Application of the multi-step EPD technique to fabricate thick TiO 2 layers: effect of organic medium viscosity on the layer microstructure," The Journal of Physical Chemistry $B$, vol. 117, no. 6, pp. 1731-1737, 2013.

[31] K. Wu, Y. Wang, and I. Zhitomirsky, "Electrophoretic deposition of $\mathrm{TiO} 2$ and composite $\mathrm{TiO} 2-\mathrm{MnO} 2$ films using benzoic acid and phenolic molecules as charging additives," Journal of Colloid and Interface Science, vol. 352, no. 2, pp. 371-378, 2010.

[32] A. R. Boccaccini, P. Karapappas, J. M. Marijuan, and C. Kaya, "TiO2 coatings on silicon carbide and carbon fibre substrates by electrophoretic deposition," Journal of Materials Science, vol. 39, no. 3, pp. 851-859, 2004.

[33] K. Hasegawa, M. Tatsumisago, and T. Minami, "Preparation of thick silica films by the electrophoretic sol-gel deposition using a cationic polymer surfactant," Journal of the Ceramic Society of Japan, vol. 105, no. 7, pp. 569-572, 1997.

[34] S. E. Khier, W. A. Brantley, and R. A. Fournelle, "Bending properties of superelastic and nonsuperelastic nickel-titanium orthodontic wires," American Journal of Orthodontics and Dentofacial Orthopedics, vol. 99, no. 4, pp. 310-318, 1991.

[35] T. Yoneyama, H. Doi, E. Kobayashi, and H. Hamanaka, "Superelastic property of Ti-Ni alloy for use in dentistry," Frontiers of Medical and Biological Engineering, vol. 10, no. 2, pp. 97-103, 2000.

[36] J. Berger and T. Waram, "Force levels of nickel titanium initial archwires," Journal of Clinical Orthodontics, vol. 41, no. 5, pp. 286-292, 2007.

[37] N. Serpone, A. Salinaro, S. Horikoshi, and H. Hidaka, "Beneficial effects of photo-inactive titanium dioxide specimens on plasmid DNA, human cells and yeast cells exposed to UVA/UVB simulated sunlight," Journal of Photochemistry and Photobiology A: Chemistry, vol. 179, no. 1-2, pp. 200-212, 2006.

[38] R. C. Gopalan, I. F. Osman, A. Amani, M. De Matas, and D. Anderson, "The effect of zinc oxide and titanium dioxide nanoparticles in the Comet assay with UVA photoactivation of human sperm and lymphocytes," Nanotoxicology, vol. 3, no. 1, pp. 33-39, 2009.

[39] W. F. Vevers and A. N. Jha, "Genotoxic and cytotoxic potential of titanium dioxide ( $\mathrm{TiO} 2)$ nanoparticles on fish cells in vitro," Ecotoxicology, vol. 17, no. 5, pp. 410-420, 2008.

[40] R. S. Woodruff, Y. Li, J. Yan et al., "Genotoxicity evaluation of titanium dioxide nanoparticles using the Ames test and Comet assay," Journal of Applied Toxicology, vol. 32, no. 11, pp. 934-943, 2012.

[41] M. A. Smith, R. Michael, R. G. Aravindan et al., "Anatase titanium dioxide nanoparticles in mice: Evidence for induced structural and functional sperm defects after short-, but not long-, term exposure," Asian Journal of Andrology, vol. 17, no. 2, pp. 261-268, 2015.

[42] T. H. Umbreit, S. Francke-Carroll, J. L. Weaver et al., "Tissue distribution and histopathological effects of titanium dioxide nanoparticles after intravenous or subcutaneous injection in mice," Journal of Applied Toxicology, vol. 32, no. 5, pp. 350-357, 2012.

[43] J. Chen, X. Dong, J. Zhao, and G. Tang, "In vivo acute toxicity of titanium dioxide nanoparticles to mice after intraperitioneal 
injection," Journal of Applied Toxicology, vol. 29, no. 4, pp. 330337, 2009.

[44] A. M. Schrand, M. F. Rahman, S. M. Hussain, J. J. Schlager, D. A. Smith, and A. F. Syed, "Metal-based nanoparticles and their toxicity assessment," Wiley Interdisciplinary Reviews: Nanomedicine and Nanobiotechnology, vol. 2, no. 5, pp. 544$568,2010$.

[45] S. Boland, S. Hussain, and A. Baeza-Squiban, "Carbon black and titanium dioxide nanoparticles induce distinct molecular mechanisms of toxicity," Wiley Interdisciplinary Reviews: Nanomedicine and Nanobiotechnology, vol. 6, no. 6, pp. 641-652, 2014. 


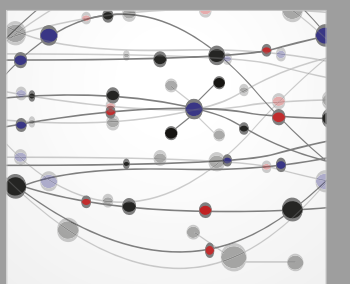

The Scientific World Journal
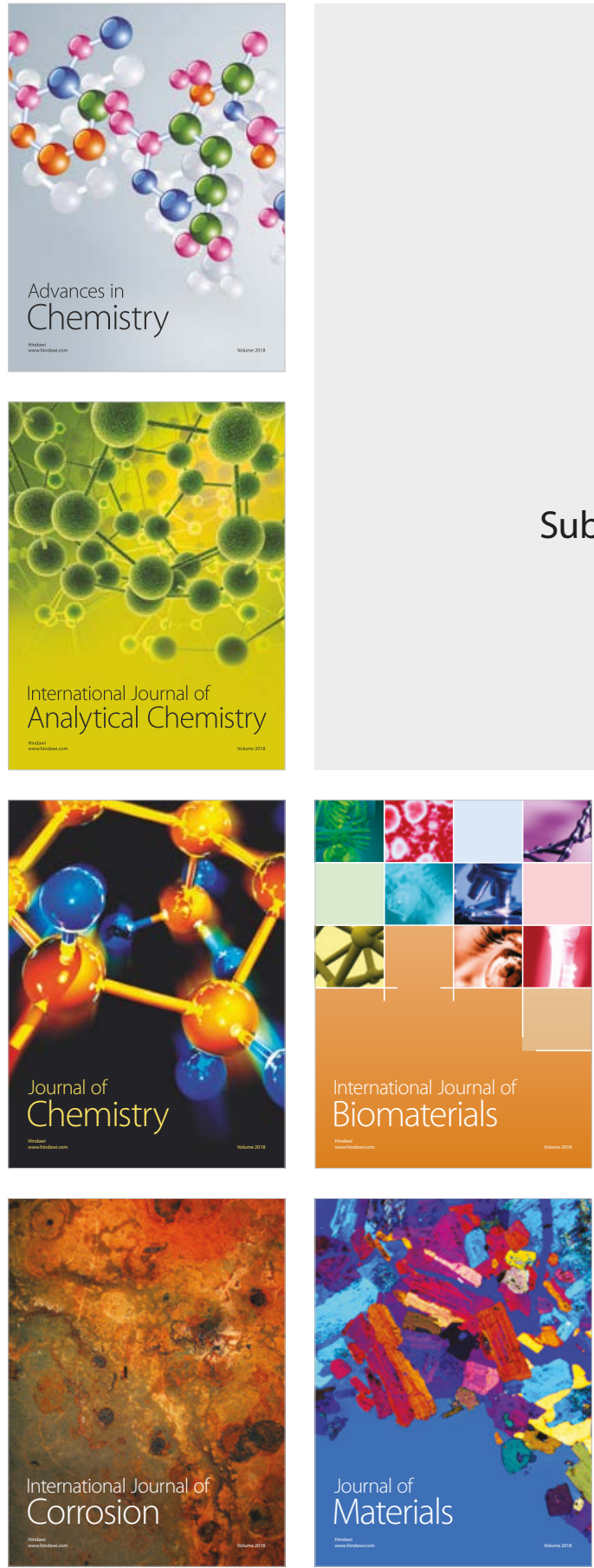

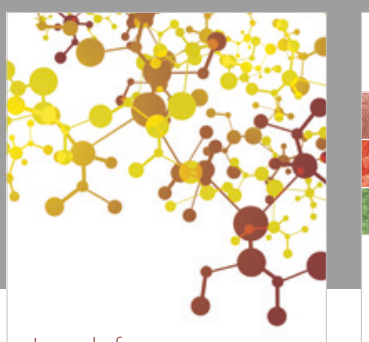

Journal of

Applied Chemistry
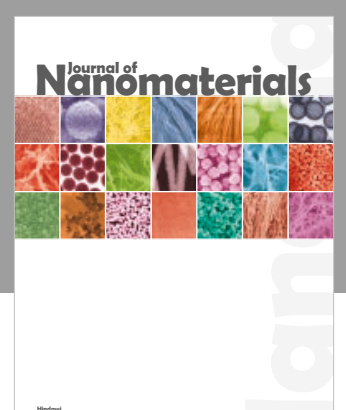

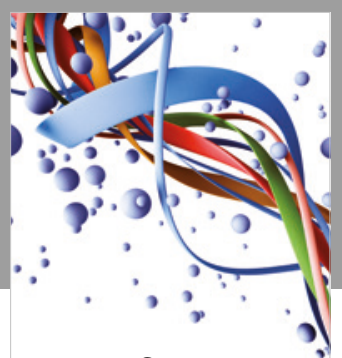

Scientifica

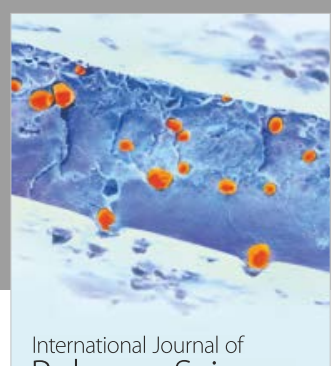

Polymer Science

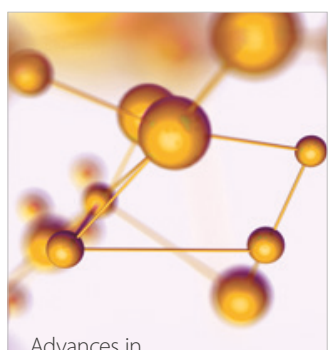

Physical Chemistry
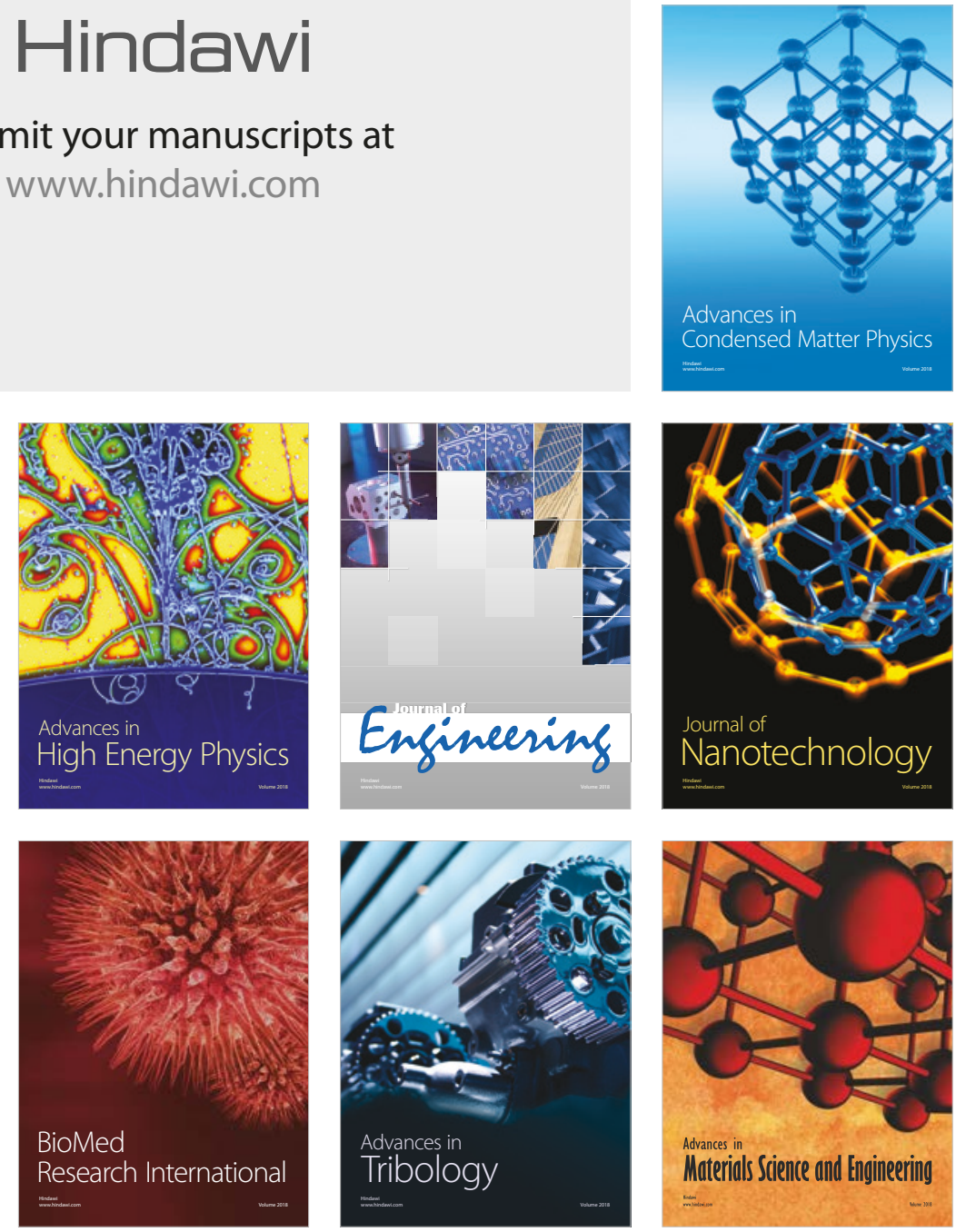